\title{
Yield, water use efficiency, and yield response factor in carrot crop under different irrigation depths
}

\author{
Produtividade, eficiência no uso da água e fator de resposta \\ em produção de cenoura sob diferentes lâminas de irrigação
}

\section{Daniel Fonseca de Carvalho $^{I^{*}}$ Dionizio Honório de Oliveira Neto ${ }^{\text {II }}$ Luiz Fernando Felix ${ }^{\text {III }}$ José Guilherme Marinho Guerra ${ }^{\text {IV }}$ Conan Ayade Salvador ${ }^{\mathrm{I}}$}

\section{ABSTRACT}

The aim of the present study was to evaluate the effect of different irrigation depths on the yield, water use efficiency (WUE), and yield response factor (Ky) of carrot (cv. 'Brasilia') in the edaphoclimatic conditions of Baixada Fluminense, RJ, Brazil. Field trials were conducted in a Red-Yellow Argisol in the 2010-2011period. A randomized block design was used, with 5 treatments (depths) and 4 replicates. Depths were applied by drippers with different flow rates, and the irrigation was managed by time domain reflectometry (TDR) technique. The reference (ETo) and crop (ETc) evapotranspiration depths reached 286.3 and $264.1 \mathrm{~mm}$ in 2010, and 336.0 and $329.9 \mathrm{~mm}$ in 2011, respectively. The root yield varied from 30.4 to $68.9 \mathrm{t} \mathrm{ha}^{-1}$ as a response to treatments without irrigation and $100 \%$ replacement of the soil water depth, respectively. Values for WUE in the carrot crop varied from 15 to $31 \mathrm{~kg} \mathrm{~m}^{-3}$ and the mean Ky value was 0.82 . The mean values for $K c$ were obtained in the initial (0.76), intermediate (1.02), and final (0.96) stages. Carrot crop was influenced by different water depths (treatments) applied, and the highest value for WUE was obtained for $63.4 \%$ of soil water replacement.

Key words: Daucus carota, crop water requirement, soil water balance, TDR, organic production.

\section{RESUMO}

$O$ objetivo deste estudo foi avaliar o efeito de diferentes lâminas de irrigação na produtividade, na eficiência de uso da água (EUA) e no coeficiente de resposta de produção (Ky) da cenoura (cv. 'Brasília') ao déficit hídrico do solo, nas condições edafoclimáticas da Baixada Fluminense-RJ. Ensaios de campo foram conduzidos em 2010 e 2011, em um Argissolo VermelhoAmarelo, usando um delineamento em blocos casualizados, com 5 tratamentos (lâminas) e 4 repetições. As lâminas foram aplicadas por gotejadores com diferentes vazões e o manejo da irrigação foi realizado com a técnica da TDR. As lâminas de evapotranspiração de referência (ETo) e da cultura (ETc) totalizaram 286,3 e 264,1 mm, em 2010, e 336,0 e 329,9mm, em 2011, respectivamente. A produtividade de raizes variou de 30,4 a 68,9t ha $\mathrm{t}^{-1}$ como resposta aos tratamentos sem irrigação e com $100 \%$ de reposição da lâmina de água no solo, respectivamente. Os valores de EUA no cultivo da cenoura variaram de 15 a $31 \mathrm{~kg} \mathrm{~m}^{-3}$ e o Ky médio foi de 0,82 . Foram obtidos os valores médios de Kc nas fases inicial $(0,76)$, intermediária $(1,02)$ e final $(0,96)$. A cultura da cenoura foi influenciada pelas diferentes lâminas aplicadas (tratamentos) e a maior EUA foi obtida para o tratamento com reposição de $63,4 \%$ da água do solo.

Palavras-chave: Daucus carota, necessidade hidrica da cultura, balanço de água no solo, TDR, produção orgânica.

\section{INTRODUCTION}

Carrot (Daucus carota L.) is an important short-cycle vegetable. It is considered the main tuberous vegetable in economic value in Brazil (LUZ et al., 2009), with more than 28,000 ha cultivated and a root production higher than 750000 tons (SILVA et al., 2012). The carrot crop is expressive in the tropical and subtropical areas. It requires appropriate soil temperature and moisture, especially during the growth stage (ROSENFELD et al., 1998), and areas with

\footnotetext{
IDepartamento de Engenharia, Instituto de Tecnologia, Universidade Federal Rural do Rio de Janeiro (UFRRJ), 23897-000, Seropédica, RJ, Brasil. E-mail: carvalho@ufrrj.br. "Corresponding author.

IIAgristar do Brasil, Santo Antonio de Posse, SP, Brasil.

IIIVia Agrícola Ltda., Uberaba, MG, Brasil.

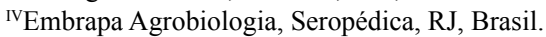


excessive soil moisture are considered unsuitable for cultivation (ISLAM et al., 1998).

Due to the high economic value of carrot, irrigation planning and management should be adopted to obtain maximum efficiency. However, maximum yield not always correspond to the highest levels of water use efficiency (WUE) as well as maximum economic return. According to STEWART et al. (1977), it is possible to estimate the crop yields for different water depths applied. However, it is necessary to know the yield response factor (Ky) under water deficit, which has not been reported for carrot crops (DOORENBOS \& KASSAM, 1994). NAGAZ et al. (2012) obtained WUE values for irrigation depths corresponding to crop evapotranspiration $\left(100 \% \mathrm{ETc} ; 8.53 \mathrm{~kg} \mathrm{~m}^{-3}\right)$ and deficit irrigation $\left(60 \% \mathrm{ETc}: 9.23 \mathrm{~kg} \mathrm{~m}^{-3}\right)$. IMTIYAZ et al. (2000) obtained average commercial yields (37.7 and $\left.38.4 \mathrm{t} \mathrm{ha}^{-1}\right)$ corresponding to different irrigation intervals (WUE: 3.73 and $6.66 \mathrm{~kg} \mathrm{~m}^{-3}$, respectively).

In Brazil, due to an increase in the competitive use of water resources and decrease in the water irrigation quality, crop area has become restricted, requiring a higher yield per unit area and water applied (JENSEN, 2007). In this sense, the use of more efficient irrigation systems, associated with studies to evaluate crop performance under controlled water deficit (DOMÍNGUEZ et al., 2012), became important tools in the search for higher WUE associated with quantitatively and qualitatively acceptable yields (LOVELLI et al., 2007), even in organic production systems (MIGLIORINI et al., 2014). Organic farming has been both encouraged by public policies for rural development and gradually accepted by consumers. These facts can be justified by the growing concern with the environment and food security (KERSELAERS et al., 2007).

In view of the need to optimize the use of resources in the agriculture and the growing demand for organic products, this study was conducted in order to estimate yield, water use efficiency, and yield response factor under water deficit of organic carrot in the edaphoclimatic conditions of Baixada Fluminense, RJ, Brazil.

\section{MATERIALS AND METHODS}

Two experiments were conducted in the Sistema Integrado de Produção Agroecológica (SIPA), in the municipality of Seropédica (coordinates: $22^{\circ} 46^{\circ}$ S e $43^{\circ} 41^{\prime} \mathrm{W}$; area: 59 ha; average height: $\left.33 \mathrm{~m}\right)$, RJ, Brazil. According to CARVALHO et al. (2013), the climate in the region is classified as Aw (Köppen classification), with high temperatures and rains in summer, and dry weather with mild temperatures in winter. The rains are concentrated in the period Nov-Mar (annual averages for: rainfall: 1213mm; temperature: $24.5^{\circ} \mathrm{C}$ ).

The areas intended for experimentation were prepared with one plowing and two harrowings and, then they were mechanically embedded. The soil is classified as Red-Yellow Argisol (layer: 0-20cm; clay: $22 \%$; silt: $8 \%$; and sand: $70 \%$ ) and its chemical composition $\left(\mathrm{Ca}^{2+}: 2.8 ; \mathrm{Mg}^{2+}: 1.1\right.$; $\mathrm{K}^{+}$: 104; and $\mathrm{P}: 69.8 \mathrm{cmol}_{\mathrm{c}} \mathrm{dm}^{-3}$; and $\left.\mathrm{pH}: 5.9\right)$ was characterized according to the methodology proposed by EMBRAPA (1997). Analyzes were performed before the initial tillage with samples collected in the experimental area (depth: $0-20 \mathrm{~cm}$; effective depth of the carrot root system). In view of the results obtained, correction or basic fertilization were not carried out in the soil.

Carrot (cv. 'Brasília') was cultivated in 2010 (sowed in June) and 2011 (sowed in August). Sowing was performed in a continuous line and spaced by $25 \mathrm{~cm}$. After chopping (25 days after sowing, DAS), the plants were spaced by $5 \mathrm{~cm}$. Cured cattle manure (composed of $\mathrm{Ca}^{2+}: 10.7 ; \mathrm{Mg}^{2+}: 2.7 ; \mathrm{K}^{+}$: 12.3; and P: $2.2 \mathrm{cmol}_{\mathrm{c}} \mathrm{dm}^{-3}$; and $\mathrm{N}: 1.4 \%$ ) was used in fertilization (dose: $73 \mathrm{~g} \mathrm{~m}^{-1}$ on line; based on dry mass weight), which was performed soon after sowing, just to cover the seeds. This quantity of manure corresponds to an average amount of $3 \mathrm{Mg} \mathrm{ha}^{-1}$. At $30 \mathrm{DAS}$, topdressing fertilization was also performed on-line with castor bean cake, characterized by $\mathrm{Ca}^{2+}$ : 12.95; $\mathrm{Mg}^{2+}: 6.55 ; \mathrm{K}^{+}: 8.5$; and P: $2.42 \mathrm{cmol}_{\mathrm{c}} \mathrm{dm}^{-3}$; and $\mathrm{N}$ : $5.81 \%$, (dose: $\left.1.5 \mathrm{Mg} \mathrm{ha}^{-1}\right)$.

The experimental design of randomized blocks was adopted, with 5 treatments (depths) and 4 repetitions, in a total of 20 experimental plots of $1.15 \mathrm{~m}^{2}$. Distinct irrigation depths were obtained with drippers of different flow rates $(3.9 ; 6.5 ; 9.0$; and $\left.10.8 \mathrm{~L} \mathrm{~h}^{-1}\right)$, which respectively corresponded to 43 (T2), 72 (T3), 100 (T4) and 120\% (T5) of the crop evapotranspiration (ETc). Treatment $\mathrm{T} 1$ consisted of irrigation water (applied with a sprinkler, in the crop establishment period) and effective precipitation (which occurred during the experiment). At the end of the experiment, 14 plants per plot were evaluated.

The irrigation management was based on the water balance in the soil (Equation 1), and the water content $(\theta)$ was monitored by means of the Time Domain Reflectometry (TDR) technique (TOPP et al., 1980). Therefore, $15 \mathrm{~cm}$ length probes were built, placed horizontally in the soil, and then calibrated according to the methodology described 
by LIMA et al. (2012). The TDR100 (Campbell Sci.) equipment was used to determine the dielectric constant of the medium (ka). Daily readings were made by using the 2.07 PCTDR software, and the values were used in calibration equations to obtain the $\theta$ value. Probes were installed (depths: 10 and $20 \mathrm{~cm}$ ) in the plots corresponding to treatment $\mathrm{T} 4$, and irrigation management was carried out considering the effective depths of 5, 10, and $20 \mathrm{~cm}$.

$\mathrm{ETc}=\mathrm{I}+\mathrm{Ep}-\mathrm{RO}-\mathrm{Dd}+\mathrm{CR} \pm \Delta \mathrm{SF} \pm \Delta \mathrm{SW}$

in which I: irrigation; Ep: effective precipitation; RO: run-off; Dd: deep drainage; CR: capillary rise; $\triangle \mathrm{SF}$ : variation in the subsurface inflow and outflow; and $\Delta \mathrm{SW}$ : variation in soil water storage (all terms of the equation in $\mathrm{mm}$ ).

The irrigation depth was determined considering an every 2 days irrigation schedule to raise $\theta$ to the field capacity $\left(0.181 \mathrm{~cm}^{3} \mathrm{~cm}^{-3}\right)$, which was previously predetermined in a field test. The RO, $\mathrm{CR}$, and $\triangle \mathrm{SF}$ terms of the equation were considered null, given the characteristics of the area and irrigation system used (GARCIA y GARCIA et al., 2009). Although the water amount applied by irrigation has been enough to raise $\theta$ to the field capacity, Dd and $\Delta \mathrm{SW}$ were also monitored by TDR. The Ep term was determined for each treatment according to the methodology described by CARVALHO et al. (2013). It consisted of the fraction of the precipitated depth that contributed to raise the soil moisture to the field capacity in the depth corresponding to the root system.

The meteorological data from an automatic station installed close to the experiment area was used in order to estimate the reference evapotranspiration (ETo) by using the Penman-Monteith (FAO-56) equation (ALLEN et al., 1998). The average carrot crop coefficients $(\mathrm{Kc})$ for the initial, middle, and final stages (ALLEN et al., 1998) were determined in both (2010 and 2011) culture cycles, by using the ratio between ETc and ETo (CARVALHO et al., 2013). In each experimental unit, the root fresh weight was determined for 14 plants by using a $0.01 \mathrm{~g}$ precision scale. Then, the roots were classified commercially following the methodology described by CEAGESP (1999), and the total and commercial carrot yields were calculated. Additionally, the WUE was calculated using the ratio between the commercial yield and the water depth applied to the crop (irrigation + Ep), and the Ky value was estimated with basis on the Stewart equation (Equation 2).

$$
\left(1-\frac{\mathrm{Y}_{\mathrm{r}}}{\mathrm{Y}_{\mathrm{m}}}\right)=\mathrm{Ky}\left(1-\frac{\mathrm{ET}_{\mathrm{a}}}{E \mathrm{~T}_{\mathrm{m}}}\right)
$$

in which $\mathrm{Y}_{\mathrm{r}}$ : real yield; $\mathrm{Y}_{\mathrm{m}}$ : maximum potential yield; $\mathrm{ET}_{\mathrm{a}}$ : actual evapotranspiration; and, $\mathrm{ET}_{\mathrm{m}}$ : maximum crop evapotranspiration.

Since this relationship is linear, Ky correspond to the slope of the regression line, which was obtained interactively by maximizing the $\mathrm{Y}_{\mathrm{m}}$ value so that the equation intercept with the ordinate axis became equal to zero. The procedure was performed in an electronic datasheet (MS Excel), using the Solver module.

Results were submitted to analysis of variance $(\mathrm{P}<0.05)$ when there was significance. Mean values were compared by Tukey test $(\mathrm{P}<0.05)$ and the values for the WUE were tested by using the polynomial regression models (MACHADO \& CONCEIÇÃO, 2007). The models were chosen with basis on statistical significance ( $\mathrm{F}$ test), adjustment in the determination coefficient $\left(\mathrm{R}^{2}\right)$, and biological significance of the model.

\section{RESULTS AND DISCUSSION}

In the field trials, the crop cycles had 90 (2010) and 94 (2011) days (Table 1). The values for total $\mathrm{ET}_{\mathrm{o}}$ were equal to $286.3 \mathrm{~mm}$ (calculated $\mathrm{ET}_{\mathrm{c}}$ : $264.1 \mathrm{~mm}$ ) in 2010 and $336.1 \mathrm{~mm}$ (calculated ET: $329.9 \mathrm{~mm}$ ) in 2011 . From the crop water requirements and reference evapotranspiration depths, mean Kc values were obtained for the carrot in the initial (0.76), intermediate (1.02), and final (0.96) stages. These values are lower than those proposed by CARVALHO et al. (1995) and SANTOS et al. (2009) in different regions in Brazil (0.8 and in the range 1.2-1.4, respectively). However, they are very close to those proposed by the FAO (ALLEN et al., 1998; 0.7, 1.05, and 0.95) and MONTENEGRO et al. $2010(0.7,1.05$, and 0.9$)$. The cultivars, climate conditions, irrigation systems, management practices adopted, and soil types could explain the differences reported in the study. LUNARDI \& LAPERUTA FILHO (1999) evaluated the crop coefficients for carrot (cv. 'Nantes Superior') by means of a constant-level lysimeter in Botucatu, SP, Brazil. The authors obtained $\mathrm{k}_{\mathrm{c}}$ values of $0.57,1.47$, and 1.14, respectively, for the same growth stages.

The water depths applied (irrigation+Ep) ranged from 67.8 to $285.5 \mathrm{~mm}$ due to the different treatments applied to the carrot crop in 2010 (Table 2). In 2011, the water depths varied from 120.0 to $351.6 \mathrm{~mm}$ due to a higher demand in evapotranspiration. It is noteworthy that water depths of 244.4 (2010) and $308.8 \mathrm{~mm}$ (2011) were applied in treatment T4 (100\% of ETc), which was considered 
Table 1 - Development stages for carrot crops and reference (ETo) and culture (ETc) evaporotranspiration depths in 2010 and 2011.

\begin{tabular}{|c|c|c|c|c|c|c|c|c|c|c|}
\hline \multirow[t]{2}{*}{ Stages } & -------- & S------------' & \multirow{2}{*}{$\begin{array}{c}d^{5} \\
\text { (days) }\end{array}$} & \multirow{2}{*}{$\begin{array}{c}\text { ETo } \\
------(m m\end{array}$} & \multirow[t]{2}{*}{ ETc } & \multicolumn{2}{|c|}{---------------Dates------------- } & \multirow{2}{*}{$\begin{array}{c}d^{5} \\
\text { (days) }\end{array}$} & \multirow{2}{*}{ ETo } & \multirow{2}{*}{ ETc } \\
\hline & Start & End & & & & Start & End & & & \\
\hline $\mathrm{IN}^{1}$ & 16 Jun & 05 Jul & 20 & 59.0 & 37.2 & 02 Aug & $21 \mathrm{Aug}$ & 20 & 63.8 & 48.4 \\
\hline $\mathrm{RG}^{2}$ & $06 \mathrm{Jul}$ & 01 Aug & 27 & 79.5 & 70.5 & $22 \mathrm{Aug}$ & 20 Sep & 30 & 104.7 & 91.1 \\
\hline $\mathrm{IT}^{3}$ & 02 Aug & 31 Aug & 30 & 97.2 & 98.2 & $21 \mathrm{Sep}$ & $20 \mathrm{Oct}$ & 30 & 108.2 & 122.7 \\
\hline \multirow[t]{2}{*}{$\mathrm{FN}^{4}$} & 01 Sep & 13 Sep & 13 & 50.6 & 58.1 & $21 \mathrm{Oct}$ & $03 \mathrm{Nov}$ & 14 & 59.4 & 67.7 \\
\hline & & TOTAL & 90 & 286.3 & 264.1 & & & 94 & 336.1 & 329.9 \\
\hline
\end{tabular}

${ }^{1} \mathrm{IN}$ : Initial; ${ }^{2} \mathrm{RG}$ : Rapid growth; ${ }^{3} \mathrm{IT}$ : Intermediate; ${ }^{4} \mathrm{FN}$ : Final; ${ }^{5} \mathrm{~d}$ : duration.

as a reference in this study. Conversely, water depths of 67.0 (2010) and $120.0 \mathrm{~mm}$ (2011) characterized treatment $\mathrm{T} 1$, and corresponded to the depths applied by sprinkling in the crop period establishment and the effective rainfall as evaluated in the period.

The commercial yields showed differences between treatments, being up to 2.5 (2010) and 3.0 (2011) times higher, as compared to treatments T4 and T1 (Table 2). Conversely, treatment T1 provided a drastic reduction in the yield of carrot roots. These results are in agreement with those found by NAGAZ et al. (2012), who reported a reduction in the carrot crop yield applying irrigation depths corresponding to 60 and $80 \%$ of ETc. Furthermore, the irrigation depth value (T5), which is above the crop water requirement, did not cause increase in the crop yield. Several studies have reported a substantial increase in crop yields, as a result of an appropriate irrigation management (NAGAZ et al., 2012). In 2010 and 2011, maximum total (62.7 and
$62.8 \mathrm{Mg} \mathrm{ha}^{-1}$ ) and commercial (47.9 and $56.9 \mathrm{Mg} \mathrm{ha}^{-1}$ ) yields were obtained, respectively. In the present study, it was used the same variety as that used by SILVA et al. (2011), who obtained a yield of up to $60 \mathrm{t} \mathrm{ha}^{-1}$ in Itumbiara, GO, Brazil, when $150 \%$ of class A-pan evaporation (1925mm) was applied. LUZ et al. (2009) used the cvs. of the Brasilia group and obtained lower average total $\left(35.5 \mathrm{Mg} \mathrm{ha}^{-1}\right)$ and commercial yields $\left(27.4 \mathrm{Mg} \mathrm{ha}^{-1}\right)$ in the autumnwinter period in Uberlândia, MG, Brazil.

Quadratic polynomial regression models (Figure 1) were adjusted to WUE values (Table 2), and maximum values were obtained for $2010(27.3 \mathrm{~kg}$ $\mathrm{m}^{-3}$; water depth: $\left.140.0 \mathrm{~mm}\right)$ and $2011\left(24.2 \mathrm{~kg} \mathrm{~m}^{-3}\right.$ water depth: $214.6 \mathrm{~mm})$. These values for water depth correspond to 57.3 (2010) and 69.5\% (2011) replacement of soil water. SILVA et al. (2011) obtained only $3.32 \mathrm{~kg} \mathrm{~m}^{-3}$ for maximum WUE when the irrigation depth applied was equivalent to $90 \%$ of class-A pan evaporation.

Table 2 - Total and commercial yields of carrot roots and water use efficiency (WUE) in both years of cultivation under different water depths applied (WDA).

\begin{tabular}{|c|c|c|c|c|c|c|c|c|}
\hline \multirow{3}{*}{ Treatments } & \multicolumn{4}{|c|}{---------------------------------2010------------------------------- } & \multirow{2}{*}{\multicolumn{3}{|c|}{ WDA $\quad$---------Yield $\left(\mathrm{Mg} \mathrm{ha}^{-1}\right)$---------- }} & \multirow{3}{*}{$\begin{array}{l}\text { WUE } \\
\left(\mathrm{kg} \mathrm{m}^{-3}\right)\end{array}$} \\
\hline & \multirow{2}{*}{$\begin{array}{l}\text { WDA } \\
(\mathrm{mm})\end{array}$} & \multicolumn{2}{|c|}{-------Yield $\left(\mathrm{Mg} \mathrm{ha}^{-1}\right)$--------- } & \multirow{2}{*}{$\begin{array}{l}\text { WUE } \\
\left(\mathrm{kg} \mathrm{m}^{-3}\right)\end{array}$} & & & & \\
\hline & & Total & Commercial & & $\begin{array}{l}\text { WDA } \\
(\mathrm{mm})\end{array}$ & Total & Commercial & \\
\hline$\overline{\mathrm{T} 1}$ & 67.8 & $30.7 \mathrm{c}$ & $15.3 \mathrm{~b}$ & $22.6 \mathrm{ab}$ & 120.0 & $31.7 \mathrm{~b}$ & $22.8 \mathrm{~b}$ & $19.0 \mathrm{ab}$ \\
\hline $\mathrm{T} 2$ & 130.9 & $47.5 \mathrm{~b}$ & $40.6 \mathrm{a}$ & $31.0 \mathrm{a}$ & 190.9 & $53.7 \mathrm{a}$ & $48.9 \mathrm{a}$ & $25.6 \mathrm{a}$ \\
\hline $\mathrm{T} 3$ & 188.9 & $52.9 \mathrm{~b}$ & $44.3 \mathrm{a}$ & $23.4 \mathrm{ab}$ & 251.1 & $59.5 \mathrm{a}$ & $56.2 \mathrm{a}$ & $22.4 \mathrm{ab}$ \\
\hline $\mathrm{T} 4$ & 244.4 & $62.7 \mathrm{a}$ & $47.9 \mathrm{a}$ & $19.6 \mathrm{ab}$ & 308.8 & $62.8 \mathrm{a}$ & $56.9 \mathrm{a}$ & $18.4 \mathrm{ab}$ \\
\hline $\mathrm{T} 5$ & 285.5 & $53.2 \mathrm{~b}$ & $42.9 \mathrm{a}$ & $15.0 \mathrm{~b}$ & 351.6 & $57.2 \mathrm{a}$ & $53.8 \mathrm{a}$ & $15.3 \mathrm{~b}$ \\
\hline
\end{tabular}

Mean values followed by same lowercase letter between lines were not significantly different at $5 \%$ level of probability by the Skott Knot test. 


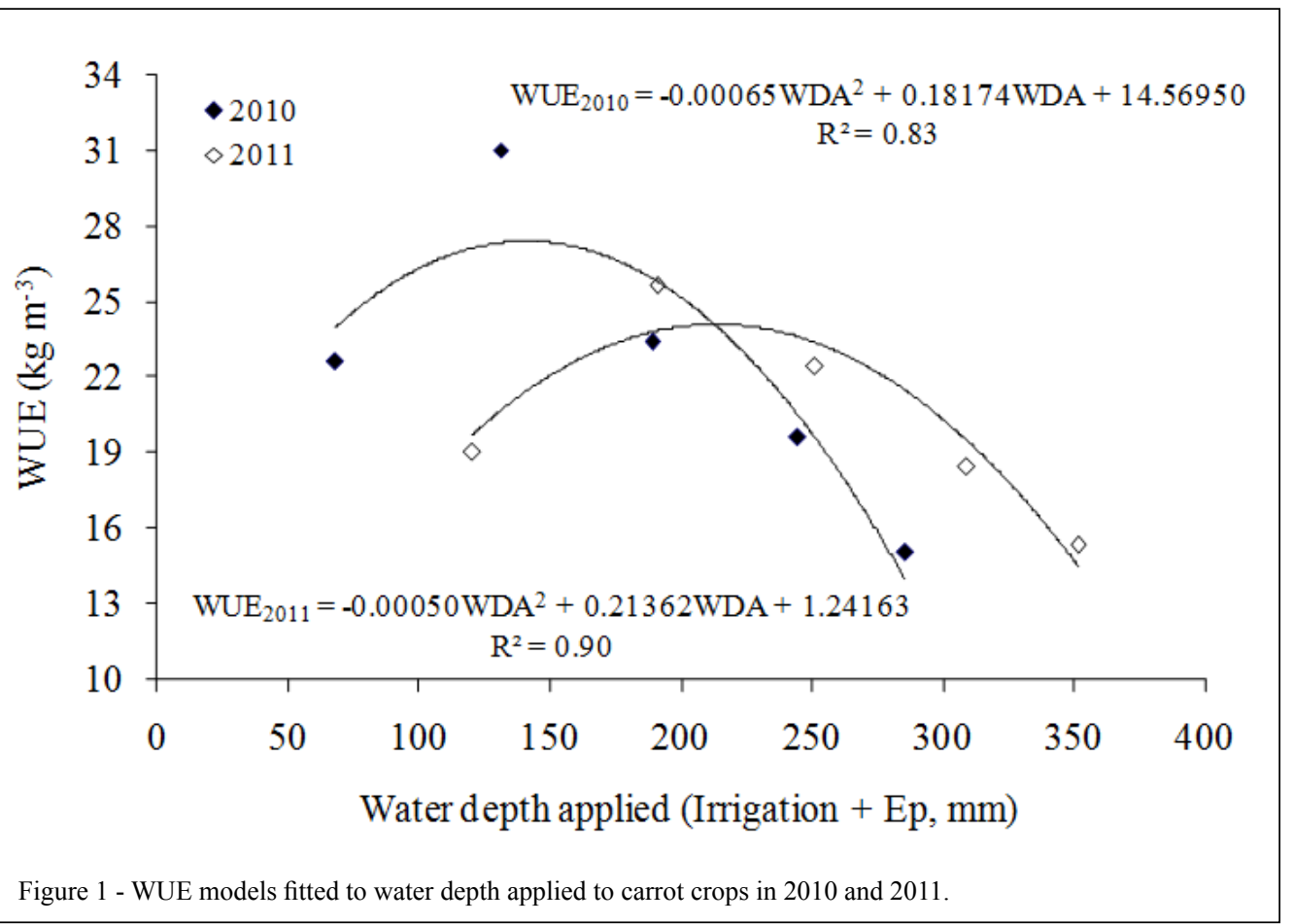

An average Ky (0.82) was obtained for the carrot crop as a response to water deficit. The Ky values lower than 1.0 indicate that the crop showed some adaptability to the water deficit. For a better control of irrigation, it is recommend more detailed studies to obtain Ky values for specific stages of crop development. Although knowledge about this parameter is important, information about the yield response factor under water deficit in carrot crops with the methodology applied in the present study were not reported in the literature.

\section{CONCLUSION}

Carrot crop was influenced by different water depths applied, and the highest WUE was obtained with average replacement of $63.4 \%$ of soil water. Results indicate that high carrot yields can be obtained under the edaphoclimatic conditions in Seropédica, RJ, Brazil, for organic farming and controlled water deficit.

\section{REFERENCES}

ALLEN, R.G. et al. Crop evapotranspiration: guidelines for computing crop water requeriments. Irrigation and Drainage, 1998. 301p. (Paper, 56). Available from: <http://www.fao.org/ docrep/x0490e/x0490e00.htm>. Accessed: Oct. 08, 2014.
CARVALHO, D.F. et al. Evapotranspiration and crop coefficient for potato in organic farm. Engenharia Agrícola, v.33, p.201-211, 2013. Available from: <http://www.scielo.br/pdf/eagri/v33n1/ v33n1a20.pdf>. Accessed: Dec. 02, 2014. doi: 10.1590/S010069162013000100020

CARVALHO, J.A. et al. Efeito da lâmina de irrigação sobre o crescimento da cenoura (Daucus carota L.) cv. 'Brasília'. Revista Ceres, v.42, p.528-542, 1995. Available from: $<$ http://www.ceres.ufv.br/ceres/revistas/V42N243P04895.pdf>. Accessed: Dec. 02, 2014.

CEAGESP. Classificação de cenoura: programa de adesão voluntária. São Paulo: Programa de Horti \& Fruti, 1999. 8p. (Folder).

DOMÍNGUEZ, A. et al. Determination of optimal regulated deficit irrigation strategies for maize in a semi-arid environment. Agricultural Water Management, v.110, p.67-77, 2012. Available from: $<$ http://www.sciencedirect.com/science/article/pii/ S0378377412001011>. Accessed: Dec. 02, 2014. doi: 10.1016/j. agwat.2012.04.002

DOORENBOS, J.; KASSAM, A.H. Efeito da água no rendimento das culturas. Trad. de GHEYI, H.R. et al. Campina Grande: UFPB, (FAO. Estudos de Irrigação e Drenagem, 33). 1994. 306p.

EMBRAPA. Centro Nacional de Pesquisa de Solos. Manual de métodos de análise de solo. 2.ed. Rio de Janeiro: 1997. 212p.

GARCIA y GARCIA, A. et al. Water use and water use efficiency of sweet corn under different weather conditions and soil moisture regimes. Agricultural Water Management, v.96, p.1369-1376, 2009. Available from: <http://www.sciencedirect.com/science/ 
article/pii/S0378377409001450>. Accessed: Dec. 02, 2014. doi: 10.1016/j.agwat.2009.04.022.

IMTIYAZ, M. et al. Response of six vegetable crops to irrigation schedules. Agricultural Water Management, v.45, p.331-342, 2000. Available from: <http://www.sciencedirect.com/science/ article/pii/S0378377499001055>. Accessed: Dec. 02, 2014. doi: 10.1016/S0378-3774(99)00105-5.

ISLAM, A.F.M.S. et al. Growth characteristics and yield of carrots grown in a soil ridge with a porous tube for soil aeration in a wet lowland. Scientia Horticulturae, v.77, p.117-124, 1998. Available from: $<$ http://www.sciencedirect.com/science/article/pii/ S0304423898001733>. Accessed: Dec. 02, 2014. doi: 10.1016/ S0304-4238(98)00173-3.

JENSEN, M.E. Beyond irrigation efficiency. Irrigation Science, v.25, p.233-245, 2007. Available from: <http://link.springer.com/ article/10.1007\%2Fs00271-007-0060-5\#>. Accessed: Dec. 02, 2014. doi: 10.1007/s00271-007-0060-5.

KERSELAERS, E. et al. Modelling farm-level economic potential for conversion to organic farming. Agricultural Systems, v.94, p.671-682, 2007. Available from: <http://www.sciencedirect.com/ science/article/pii/S0308521X07000388>. Accessed: Dec. 02, 2014. doi: 10.1016/j.agsy.2007.02.007.

LIMA, M.E. et al. Desempenho do cultivo da berinjela em plantio direto submetida a diferentes lâminas de irrigação. Revista Brasileira de Engenharia Agrícola e Ambiental, v.16, p.604610, 2012. Available from: <http://www.scielo.br/pdf/rbeaa/ v16n6/v16n06a03.pdf>. Accessed: Dec. 02, 2014. doi: 10.1590/ S1415-43662012000600003.

LOVELLI, S. et al. Yield response factor to water (ky) and water use efficiency of Carthamus tinctorius L. and Solanum melongena L. Agricultural Water Management, v.92, p.73-80, 2007. Available from: <http://www.sciencedirect.com/science/ article/pii/S0378377407001321>. Accessed: Dec. 02, 2014. doi: 10.1016/j.agwat.2007.05.005.

LUNARDI, D.M.C.; LAPARETA FILHO, J. Evapotranspiração máxima e coeficiente de cultura da cenoura (Daucus carota L.). Revista Brasileira de Agrometeorologia, v.7, n.1, p.13-17, 1999. Available from: <http://coral.ufsm.br/rba/t131771.html >. Accessed: Dec. 02, 2014.

LUZ, J.M.Q. et al. Performance of carrot cultivars in the Summer and Autumn-Winter, in Uberlandia, Brazil. Horticultura Brasileira, v.27, p.96-99, 2009. Available from: <http://www. scielo.br/pdf/hb/v27n1/19.pdf>. Accessed: Dec. 02, 2014 . doi: 10.1590/S0102-05362009000100019

MACHADO, A.A.; CONCEIÇÃO, A.R. WinStat - Sistema de análise estatística para Windows. Pelotas: Universidade Federal de Pelotas, 2007. Versão 1.0.
MIGLIORINI, P. et al. Agronomic performance, carbon storage and nitrogen utilisation of long-term organic and conventional stockless arable systems in Mediterranean area. European Journal of Agronomy, v.52, p.138-145, 2014. Available from: <http://www. sciencedirect.com/science/article/pii/S116103011300138X>. Accessed: Nov. 12, 2014. doi: 10.1016/j.eja.2013.09.017.

MONTENEGRO, S.G. et al. Improving agricultural water management in the semi-arid region of Brazil: experimental and modelling study. Irrigation Science, v.28, p.301316, 2010. Available from: <http://link.springer.com/ article/10.1007\%2Fs00271-009-0191-y\#>. Accessed: Dec. 02, 2014. doi: 10.1007/s00271-009-0191-y.

NAGAZ, K. et al. Impacts of irrigation regimes with saline water on carrot productivity and soil salinity. Journal of the Saudi Society of Agricultural Sciences, v.11, p.19-27, 2012. Available from: <http://www.sciencedirect.com/science/article/pii/ S1658077X11000361>. Accessed: Dec. 02, 2014. doi: 10.1016/j. jssas.2011.06.001.

ROSENFELD, H.J. et al. The effect of temperature on sensory quality, chemical composition and growth of carrots (Daucus carota L.) I. Constant diurnal temperature. Journal of Horticultural Science an Biotechnology, v.73, p.275-288, 1998. Available from: <http://www.jhortscib. org/Vol73/73_2/19.htm $>$. Accessed: Dec. 02, 2014. doi: $10.1080 / 14620316.1998 .11510975$.

SANTOS, F.X. et al. Determinação do consumo hídrico da cenoura utilizando lisímetros de drenagem, no agreste pernambucano. Revista Brasileira Ciência Agrária, v.4, n.3, p.304-310, 2009. Available from: <http://agraria.pro.br/sistema/index.php?journal $=$ agraria\&page $=$ article $\&$ op $=$ viewArticle \&path $\% 5 B \% 5 D=199>$. Accessed: Nov. 12, 2014. doi: 10.5039/agraria.v4i3a13.

SILVA, G.O. et al. Adaptability and stability of carrot populations. Horticultura Brasileira, v.30, p.80-83, 2012. Available from: $<$ http://www.scielo.br/pdf/hb/v30n1/v30n1a14.pdf $>$. Accessed: Nov. 12, 2014. doi: 10.1590/S0102-05362012000100014.

SILVA, V.J. et al. Resposta da cenoura à aplicação de diferentes lâminas de irrigação. Bioscience Journal, v.27, n.6, p.954963, 2011. Available from: <http:/www.seer.ufu.br/index.php/ biosciencejournal/article/view/12338>. Accessed: Dec. 02, 2014.

STEWART, J.I. et al. Optimizing crop production through control of water and salinity levels. Utah: Utah Water Res. Lab. PWRG 151-1, 1977. 191p.

TOPP, G.C. et al. Electromagnetic determination of soil water content: measurements in coaxial transmission lines. Water Resources Research, v.16, n.3, p.574-582, 1980. Available from: <http://onlinelibrary.wiley.com/doi/10.1029/ WR016i003p00574/pdf>. Accessed: Dec. 02, 2014. doi: 10.1029/WR016i003p00574. 